\title{
The Effect of Sodium Nitrite Exposure on Physiological Response of Starved Far Eastern Catfish, Silurus asotus
}

\author{
${ }^{\dagger}$ In-Seok Park ${ }^{1}$ and Hyun Woo Gil ${ }^{2}$ \\ ${ }^{1}$ Division of Marine Bioscience, College of Ocean Science and Technology, Korea Maritime and Ocean University, \\ Busan 49112, Korea \\ ${ }^{2}$ Bio-Monitoring Center, Sejong 30121, Korea
}

\begin{abstract}
The experiment was conducted for 210 days to determine the effect of feeding, and starvation, and exposure to sodium nitrite $\left(\mathrm{NaNO}_{2}\right)$ on the survival, physiological changes, hematological parameter, and stress response of Far Eastern catfish, Silurus asotus. The survival of the starved group was lower than that of the fed group during the experiment. Starvation resulted in retardation of growth, which provides an example of fish that failed to continue to grow and remain in a good condition. Blood analyses (cortisol and glucose) showed significant differences of stress response between the fed and starved groups exposed to $\mathrm{NaNO}_{2}$ at the conclusion of the experiment $(p<0.05)$. These results suggest that all nutritional parameters used for starvation and feeding with $\mathrm{NaNO}_{2}$ stress in this experiment appear to be a useful index of nutritional status in Far Eastern catfish.
\end{abstract}

Key words : Far Eastern catfish (Silurus asotus), Physiological response, Sodium nitrite, Starvation

\section{INTRODUCTION}

Most fish undergo the period of starvation because of wintering, spawning, migration, or regional decrease in food resources (Mustafa \& Mittal, 1982; Park et al., 2001, 2015). Fish can overcome starvation through biochemical, physiological, and behavioral strategies. Endogenous energy from basic metabolic accumulation in the body is spent as fish consume their own tissues to remain alive during starvation (Mustafa \& Mittal, 1982; Weatherley \& Gill, 1987; Kim et al., 2012; Park et al., 2013). During starvation, essential processes in fish are maintained at the expense of accumulated (i.e., completely endogenous) energy reserves, resulting in the progressive depletion and wast- age (degrowth) of body tissues (Weatherley \& Gill, 1987; Park et al., 2015). The observed incidence of starvation is fundamentally common based on morphological and histological criteria (Park et al., 2001).

The efficiency of oxygen consumption in fish is directly related to their metabolic processes, through which they synthesize body ingredients to produce physical energy. This, in turn, ultimately determines their population density, food supply, and fish yield (Mehner \& Wieser, 1994). Mehner and Wieser (1994) observed the relationship between the depletion of energy reserves and changes in oxygen consumption in the perch, Perca fluviatilis. Starvation reduces oxygen consumption efficiency as reported in perch larvae and the traira, Hoplias malabaricus, when

\footnotetext{
Manuscript received September 28, 2018, Received in revised form October 15, 2018, Accepted November 2, 2018

${ }^{\dagger}$ Corresponding Author : In-Seok Park, Division of Marine Bioscience, College of Ocean Science and Technology, Korea Maritime and Ocean University, Busan 49112, Korea. Tel: +82- 51-410-4321, Fax: +82-51-404-4750, E-mail: ispark@kmou.ac.kr
}

This is an Open Access article distributed under the terms of the Creative Commons Attribution Non-Commercial License (http:// creative-commons.org/licenses/by-nc/3.0) which permits unrestricted non-commercial use, distribution, and reproduction in any medium, provided the original work is properly cited. 
they were subjected to extended periods of starvation (Mehner \& Wieser, 1994; Rios et al., 2002).

Stresses on fish induce the release of catecholamine and cortisol, which cause the rapid metabolism of highenergy storage compounds (Barton \& Iwama, 1991). These catabolic processes have harmful biochemical effects on fish health and lead to slow growth (Specker \& Schreck, 1980). Fish exhibit primary, secondary, and tertiary responses to stress (Barton \& Iwama, 1991). The primary response is manifested in rapid changes in plasma catecholamine and corticosteroid. When these responses to stressful conditions exceed normal levels, harmful secondary and tertiary responses occur. Therefore, stress induces changes in the energetic metabolic processes, reduces growth rate, disturbs reproduction, and leads to rapid changes in flesh quality after death (Barton \& Iwama, 1991). Blood chemistry serves as an indicator of an animal's physiological state and many factors (age, sex, nutrition, season, and circadian rhythm) may affect the blood chemistry. Information is available from the plasma glucose changes during starvation in the Atlantic cod, Gadus morhua L., the European eel, Anguilla anguilla (Larsson \& Lewander, 1973), the pike, Esox lucius (Ince \& Thorpe, 1976), the toadfish, Opsanus tau (Tashima \& Cahill, 1968), the goldfish, Carassius auratus (Chavin \& Young, 1970), and the American eel, Anguilla rostrata (Moon, 1983). Studies of plasma free fatty acids during starvation stress have also been performed in the European eel (Larsson \& Lewander, 1973), the American eel (Moon, 1983), the rainbow trout, Oncorhynchus mykiss (Sumpter et al., 1991), the pike (Ince \& Thorpe, 1976), and the toadfish (Tashima \& Cahill, 1968). Rios et al. (2002) noted that erythrocyte senescence and hematological changes are induced by starvation in Hoplias malabaricus.

The Far Eastern catfish, Silurus asotus (Linnaeus) (order Siluriformes, family Siluridae), spreading widely throughout the Northeast Asia, is an important species in Korean freshwater aquaculture (Kim et al., 2001; Gil et al., 2017).
In this study, we tried to provide a more detailed contents, and investigated the impact of sodium nitrite on physiological response of Far Eastern catfish.

\section{MATERIALS AND METHODS}

The Far Eastern catfish, Silurus asotus used in this experiment was hatched in April 2015 and reared at Fishery Genetics and Breeding Sciences Laboratory of the Korea Maritime and Ocean University in Busan, Korea. Three experimental groups were established: initial, fed, and starved. All fish were fed twice daily with commercial feed (Table 1 ) in total $1 \%$

Table 1. Composition of the experimental diets used in this starvation experiment ${ }^{1}$

\begin{tabular}{cc}
\hline \hline Nutrition & Content (\%) \\
\hline Crude protein & 40.0 \\
Crude fat & 4.0 \\
Crude fiber & 5.0 \\
Ash & 15.0 \\
Calcium & 1.0 \\
Phosphorus & 1.0 \\
Mineral premix & \\
Vitamin premix & \\
&
\end{tabular}

1) Ehwa Feed Coporation (Busan, Korea).

2) Vitamin premix contained the following amount which were diluted in cellulose $\left(\mathrm{g} \mathrm{kg}^{-1} \mathrm{mix}\right)$ : L-ascorbic acid, 121.2; DL- $\alpha$-tocopheryl acetate, 18.8; thiamin hydrochloride, 2.7; riboflavin, 9.1; pyridoxine hydrochloride, 1.8; niacin, 36.4; Ca-D-pantothenate, 12.7; myo-inositol, 181.8; D-biotin, 0.27; folic acid, 0.68; p-aminobenzoic acid, 18.2; menadione, 1.8; retinyl acetate, 0.73; cholecalciferol, 0.003; cyanocobalamin, 0.003 .

3) Mineral premix contained the following ingredients $\left(\mathrm{g} \mathrm{kg}^{-1}\right.$ premix): $\mathrm{NaCl}, 43.3 ; \mathrm{MgSO}_{4} \cdot 7 \mathrm{H}_{2} \mathrm{O}, 136.5 ; \mathrm{NaH}_{2} \mathrm{PO}_{4} \cdot 2 \mathrm{H}_{2} \mathrm{O}$, 86.9; $\mathrm{KH}_{2} \mathrm{PO}_{4}, 239.0 ; \mathrm{CaH}_{4}\left(\mathrm{PO}_{4}\right) \cdot 2 \mathrm{H}_{2} \mathrm{O}, 135.3$; ferric citrate, 29.6; $\mathrm{ZnSO}_{4} \cdot 7 \mathrm{H}_{2} \mathrm{O}, 21.9$; Ca-lactate, 304.0; $\mathrm{CuCl}$, $0.2 ; \mathrm{AlCl}_{3} \cdot 6 \mathrm{H}_{2} \mathrm{O}, 0.15 ; \mathrm{KI}, 0.15 ; \mathrm{Na}_{2} \mathrm{Se}_{2} \mathrm{O}_{3}, 0.01 ; \mathrm{MnSO}_{4} \cdot \mathrm{H}_{2} \mathrm{O}$, 2.0; $\mathrm{CoCl}_{2} \cdot 6 \mathrm{H}_{2} \mathrm{O}, 1.0$. 
$3 \%$ food of their average body weight (BW) for 2 weeks prior to initiation of experiment in March 2016. Before the starvation experiment, fish were weighed to the nearest $0.01 \mathrm{~g}$ using an electronic balance (JW-1, Acom, Pochen, Korea), and their body length (BL) was measured to the nearest $0.01 \mathrm{~cm}$ using digital Vernier calipers $(\mathrm{CD}-20 \mathrm{CP}$, Mitytoyo, Kawasaki, Japan). The fed group had an average body weight $(\mathrm{BW})$ of $354.1 \pm 7.74 \mathrm{~g}$ and average $\mathrm{BL}$ of $18.2 \pm 2.79 \mathrm{~cm}(n=60)$. The starved group had an average BW of $356.1 \pm 9.71 \mathrm{~g}$ and average BL of $18.1 \pm 2.31 \mathrm{~cm}(n=60)$.

Fish were reared in a recirculating system. 20 fish were placed each in 1.1-ton fiberglass-reinforced plastic circular tank (118 cm diameter, $100 \mathrm{~cm}$ depth); each experimental group consisted of three tanks of fish. Light was provided with four $40-\mathrm{W}(5,400 \mathrm{~K})$ fluorescent bulbs controlled by an electric timer, which kept the photoperiod at a $12 \mathrm{~L}: 12 \mathrm{D}$ cycle. Water temperature was controlled automatically and held at $25 \pm 0.5^{\circ} \mathrm{C}$ during the experimental period. During the experiment, the fed group was hand-fed two times daily (first feeding occurred between 10:00 and 11:00 and the second between 18:00 and 19:00). The starved group was starved until the end of the starvation experiment. The fed group was given feed continuously. The fish in all experiments were kept until the starved group lost vitality completely. The survival rate during the starvation experiment was calculated retroactively, with the dead fish counted every day. The aggregate survival rates of the fed group and starved group during the experimental period were measured for each of the two triplicate groups. The acute and sublethal sodium nitrite $\left(\mathrm{NaNO}_{2}\right)$ toxicity tests were conducted over period of $96 \mathrm{hrs}$. Immediately after conclusion of the starvation experiment, for the acute and $\mathrm{NaNO}_{2}$ toxiciy tests, twenty individuals (BW: $83.3 \pm 7.26 \mathrm{~g}$; BL: $16.5 \pm 1.03 \mathrm{~cm}$ ) were placed in a 150 -L fiberglass-reinforced plastic tank containing $150 \mathrm{~L}$ of freshwater (Table 2). Nitrite (Sigma, St. Louis, MO, USA) was added to the tank to create nitrite concentration of $40-200 \mathrm{mg} / \mathrm{L}$ at intervals of $40 \mathrm{mg} / \mathrm{L}$; nitrite-free treatment served as a control.
Table 2. Acute toxicity test condition of sodium nitrite for Far Eastern catfish, Silurus asotus

\begin{tabular}{cc}
\hline \hline Test parameter ${ }^{1)}$ & Conditions \\
\hline Temperature $\left({ }^{\circ} \mathrm{C}\right)$ & $26 \pm 0.5$ \\
$\mathrm{pH}$ & $7.3 \pm 0.45$ \\
DO (dissolved oxygen, $\mathrm{mg} / \mathrm{L} ;$ & 8.2 \\
Saturated concentration in $\left.26^{\circ} \mathrm{C}\right)$ & $2.8 \pm 0.33$ \\
Salinity (ppt) & 0.02 \\
Ammonia (ppm) & $2.4 \pm 0.12$ \\
Nitric acid (ppm) & 0.01 \\
Nitrous acid (ppm) & 238 \\
Conductivity (us $/ \mathrm{cm})$ &
\end{tabular}

1) Temperature, $\mathrm{pH}$, dissolved oxygen, and salinity were measured using an oxygen measurement electrode and a multi-data logger system (Oxyguard, Denmark). Ammonia, nitric acid, nitrous acid, and conductivity were measured using spectrophotometer (DR 2800, HACH, Loveland, Colorado, USA). The values are means of triplicate groups.

Three replications were used for each test concentration and control. Determining lethal concentration of fifty $\left(\mathrm{LC}_{50}\right)$ values and other related statistical analysis was based upon the method described by Peltier (1978).

Immediately after conclusion of the starvation experiment, the oxygen consumption rate was measured according to the method of Jo \& Kim (1999). For the measurement of oxygen consumption rate, the respirometer chamber was utilized by a simple circulating system. The water was circulated from the reservoir $(170 \mathrm{~L})$ to the head tank by a circulating pump, passing by a respirometer chamber and then flowing back into the reservoir. The head tank was equipped with a temperature controller and $10 \mu \mathrm{m}$ and $3 \mu \mathrm{m}$ cartridge filters equipped for the filtering of particles. The flow through UV lamp was utilized for the reduction of oxygen consumption by microbes. Water from the respirometer chamber flowed into an oxygen measurement chamber. During the period of experiment, the average 
water flow was $59.6 \pm 0.5 \mathrm{~L} / \mathrm{h}$. The respirometer chamber was comprised of an acrylic resin box with a thickness of 8 $\mathrm{mm}$; the overall dimensions of the box were $10 \mathrm{~cm}$ (width) $\times$ $25 \mathrm{~cm}$ (length) $\times 10 \mathrm{~cm}$ (height). A rubber pad was used as a cover for the respirometer chamber to prevent the inflow of air; a hole was made in the cover and a small valve was attached for the removal of air in the respirometer chamber. Inflow water in the respirometer chamber was diffused through a $10 \mathrm{~mm}$ pipe with the cap at the end, where a few holes were made. Water flowing from the respirometer chamber was flowed into the dissolved oxygen measurement chamber, the dimensions of which were $10 \mathrm{~cm}$ (width) $\times$ $10 \mathrm{~cm}$ (length) $\times 6 \mathrm{~cm}$ (height). The respirometer chamber consisted of three chambers, and each chamber was connected to a dissolved oxygen measurement chamber.

Dissolved oxygen measurement chambers were equipped with an oxygen probe and air in this chamber was removed by the same method as the respirometer chamber. Dissolved oxygen was measured using an oxygen measurement electrode and a multi-data logger system (Oxyguard, Denmark). Inflow and outflow dissolved oxygen of the respirometer chamber was measured by using $\mu \mathrm{Log}$ VL 100 software at 5-minute interval over $24 \mathrm{hrs}$. Measurements of oxygen and oxygen consumption rates at each temperature were saved by the multi-data logger. After experiment started, measurement times were set at 6- hour interval over $48 \mathrm{hrs}$. Before measuring the dissolved oxygen, $\mathrm{pH}$, ammonium $\left(\mathrm{NH}_{4}^{+}\right)$concentration, carbon dioxide $\left(\mathrm{CO}_{2}\right)$ concentration, and respiratory frequency (gill cover movement) were measured using a counter and a digital timer. $\mathrm{NH}_{4}^{+}$and $\mathrm{CO}_{2}$ concentrations were measured using spectrophotometer (DR 2800, HACH, Loveland, Colorado, USA). Dissolved oxygen and $\mathrm{pH}$ were measured using an oxygen measurement electrode and a multi-data logger system (Oxyguard, Denmark). Measurements of oxygen and oxygen consumption rates at each experimental group were saved by multi-data logger, as described by Cech (1990).
For the blood analyses of cortisol, glucose, and lactic acid, blood samples were extracted from five randomly selected fish at 0 (pre), 1, 6, 12, 24, and $48 \mathrm{hrs}$ this post starvation stress test. Using syringes lined with the anticoagulant heparin blood was extracted and assayed at fixed intervals of $0,1,6,12,24$, and $48 \mathrm{hrs}$ from five experimental samples. Selected blood was filled into capillary tubes and analyzed after centrifuging at $200 \mathrm{~g}$ for $10 \mathrm{~min}$. Plasma was then collected and stored in a deep freezer (SW-UF200, Samwon Freezing Engineering, Busan, Korea) at $80^{\circ} \mathrm{C}$ until analysis. The cortisol concentration was measured using radioimmunoassay. Cortisol was determined in $50 \mu \mathrm{L}$ samples using RIA kits (Coat-A-Count TKCO Cortisol RIA Kit; DPC, USA). Mixtures of sample in $100 \mathrm{~mL}$ antiserum were incubated for $45 \mathrm{~min}$ at $37^{\circ} \mathrm{C}$, and then $1,000 \mathrm{~mL}$ separation reagent was added. The mixture was placed in a refrigerator at $4^{\circ} \mathrm{C}$ for $15 \mathrm{~min}$ and then centrifuged at $1,200 \times \mathrm{g}$ for $15 \mathrm{~min}$. Supernatant was assayed for gamma radiation using an automatic gamma counter (Cobra, Packard, USA). Plasma glucose concentration was analyzed according to methodology of Raabo and Terkildsen (1960; Kit 510, Sigma, St Louis, MO, USA), where production of $\mathrm{H}_{2} \mathrm{O}_{2}$ by glucose oxidase in the presence of $o$-dianisidine was evaluated as an absorbance increase at $450 \mathrm{~nm}$. The lactic acid concentrations were analyzed using blood automatic analysis (Boehringer Mannhein Reflotron, Germanry). Data were analyzed by one and two-way ANOVA with SPSS statistical package (SPSS 9.0, SPSS Inc., USA). The experiment was performed three times, and means were separated by using Duncan's multiple range test and they were considered significantly different at $p<0.05$ (Duncan, 1955).

\section{RESULTS}

After 210 days, the starved group of Far Eastern catfish, Silurus asotus rapidly lost vitality, and as a result, the experiment was terminated. Fig. 1 shows changes in survival 


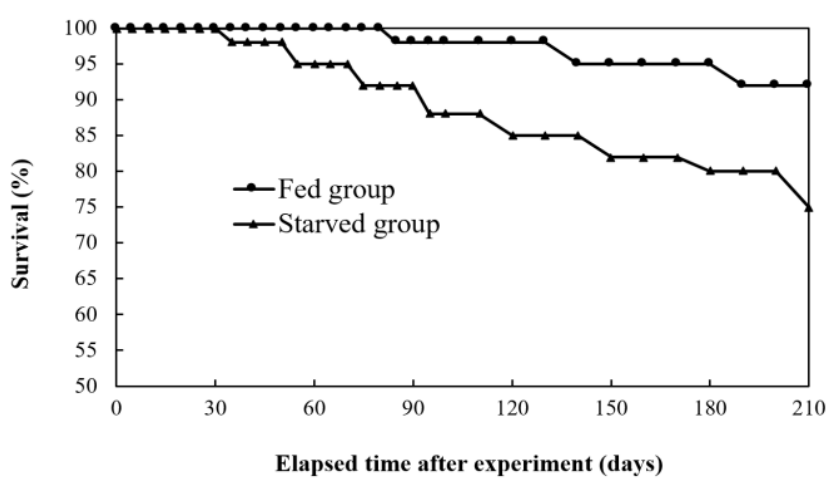

Fig. 1. Survival rates of fed and starved Far Eastern catfish, Silurus asotus for $\mathbf{2 1 0}$ days experimental period. The values are means of triplicate experiments.

rate during the experimental period. Accumulated survival was $92.2 \pm 0.47 \%$ in the fed group and $74.4 \pm 2.59 \%$ in the starved group in each triplicated tanks $(p<0.05)$. Starvation resulted in retardation of growth, which has provided a good example of the reduction of the final group continuing to grow and remaining healthy (Fig. 2).

In Tables 3 and 4, and Fig. 3, the two-way ANOVA test a

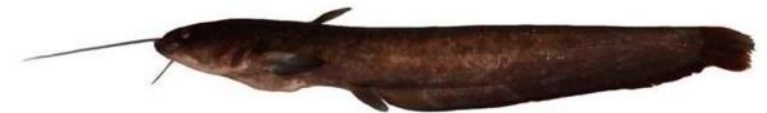

b

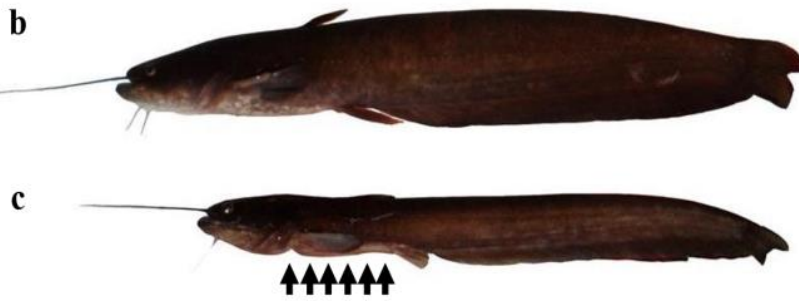

$5 \mathrm{~cm}$

Fig. 2. Typical external morphology of the Far Eastern catfish, Silurus asotusat conclusion of this starvation experiment. Initial group (a), fed group (b), and starved group (c) for 210 days period. Note the lateral ventral region in starved group is thin $\mathrm{Ar}-$ rows in Fig. 2-c).

and measurement results of oxygen consumption rate of fed and starved groups are presented. Dissolved oxygen concentration of starved groups decreased until $48 \mathrm{hrs,} \mathrm{and}$ fed groups until 16 hrs. Table 3 shows the comparison of

Table 3. Respiratory frequency (gill cover movement) and pH values between fed group and starved group of Far Eastern catfish, Silurus asotus

\begin{tabular}{|c|c|c|c|c|}
\hline \multirow{2}{*}{ Time (hrs) } & \multicolumn{2}{|c|}{ Respiratory frequency $\left(\mathrm{min}^{-1}\right)^{1)}$} & \multicolumn{2}{|c|}{$\mathrm{pH}^{1)}$} \\
\hline & Fed group & Starved group & Fed group & Starved group \\
\hline Pre-experiment & $101^{\mathrm{b}} \pm 8.7$ & $124^{\mathrm{a}} \pm 9.2$ & $7.6^{b} \pm 0.51$ & $7.6^{\mathrm{a}} \pm 0.68$ \\
\hline 6 & $102^{b} \pm 8.9$ & $128^{\mathrm{a}} \pm 8.8$ & $6.8^{b} \pm 0.45$ & $7.1^{\mathrm{a}} \pm 0.61$ \\
\hline 12 & $110^{\mathrm{b}} \pm 7.9$ & $135^{\mathrm{a}} \pm 9.9$ & $4.1^{b} \pm 0.38$ & $5.3^{\mathrm{a}} \pm 0.49$ \\
\hline 18 & $100^{\mathrm{b}} \pm 8.5$ & $124^{\mathrm{a}} \pm 10.1$ & $3.7^{b} \pm 0.25$ & $4.8^{\mathrm{a}} \pm 0.39$ \\
\hline 24 & $72^{b} \pm 5.4$ & $91^{\mathrm{a}} \pm 5.7$ & $3.5^{\mathrm{b}} \pm 0.21$ & $4.6^{\mathrm{a}} \pm 0.38$ \\
\hline 30 & $71^{b} \pm 6.2$ & $91^{\mathrm{a}} \pm 6.0$ & $3.2^{\mathrm{b}} \pm 0.20$ & $4.3^{\mathrm{a}} \pm 0.29$ \\
\hline 36 & $67^{b} \pm 4.5$ & $88^{\mathrm{a}} \pm 4.8$ & $3.0^{\mathrm{b}} \pm 0.21$ & $4.1^{\mathrm{a}} \pm 0.32$ \\
\hline 42 & $66^{\mathrm{b}} \pm 4.3$ & $80^{\mathrm{a}} \pm 5.3$ & $2.9^{\mathrm{b}} \pm 0.18$ & $4.0^{\mathrm{a}} \pm 0.28$ \\
\hline 48 & $65^{\mathrm{b}} \pm 4.1$ & $77^{\mathrm{a}} \pm 5.0$ & $2.8^{\mathrm{b}} \pm 0.12$ & $3.9^{\mathrm{a}} \pm 0.19$ \\
\hline
\end{tabular}

1) Respiratory frequency was measured while $1 \mathrm{~min}$. Difference between fed group and starved group is significant at this level $(p<0.05)$. The values are means of triplicate experiments. 
Table 4. Carbon dioxide $\left(\mathrm{CO}_{2}\right)$ and ammonium $\left(\mathrm{NH}_{4}^{+}\right)$concentration between fed group and starved group of Far Eastern catfish, Silurus asotus

\begin{tabular}{cccccc}
\hline \hline \multirow{2}{*}{$\begin{array}{c}\text { Time } \\
(\mathrm{hrs})\end{array}$} & \multicolumn{2}{c}{$\mathrm{CO}_{2}$ concentration $(\mathrm{mg} / \mathrm{L})^{1)}$} & & \multicolumn{2}{c}{ Ammonium $\left(\mathrm{NH}_{4}{ }^{+}\right)^{1)}$} \\
\cline { 2 - 3 } \cline { 5 - 6 } & Fed group & Starved group & & Fed group & Starved group \\
\hline Pre-experiment & $5.1^{\mathrm{b}} \pm 0.38$ & $5.1^{\mathrm{a}} \pm 0.41$ & & 0 & 0 \\
6 & $14.2^{\mathrm{b}} \pm 1.28$ & $13.0^{\mathrm{a}} \pm 1.19$ & & $0.13^{\mathrm{b}} \pm 0.012$ & $0.08^{\mathrm{a}} \pm 0.061$ \\
12 & $17.2^{\mathrm{b}} \pm 1.53$ & $14.6^{\mathrm{a}} \pm 1.21$ & & $0.17^{\mathrm{b}} \pm 0.015$ & $0.11^{\mathrm{a}} \pm 0.018$ \\
18 & $18.4^{\mathrm{b}} \pm 1.67$ & $16.4^{\mathrm{a}} \pm 1.59$ & & $0.19^{\mathrm{b}} \pm 0.017$ & $0.14^{\mathrm{a}} \pm 0.013$ \\
24 & $20.0^{\mathrm{b}} \pm 1.99$ & $18.6^{\mathrm{a}} \pm 1.87$ & & $0.23^{\mathrm{b}} \pm 0.020$ & \\
30 & $20.8^{\mathrm{b}} \pm 4.89$ & $19.4^{\mathrm{a}} \pm 1.78$ & & $0.24^{\mathrm{b}} \pm 0.019$ & $0.15^{\mathrm{a}} \pm 0.014$ \\
36 & $21.2^{\mathrm{b}} \pm 2.03$ & $20.0^{\mathrm{a}} \pm 1.90$ & & $0.26^{\mathrm{b}} \pm 0.018$ & $0.16^{\mathrm{a}} \pm 0.015$ \\
42 & $21.6^{\mathrm{b}} \pm 2.10$ & $20.4^{\mathrm{a}} \pm 1.98$ & & $0.28^{\mathrm{b}} \pm 0.209$ & $0.17^{\mathrm{a}} \pm 0.016$ \\
48 & $22.0^{\mathrm{b}} \pm 2.15$ & $20.6^{\mathrm{a}} \pm 2.12$ & & $0.29^{\mathrm{b}} \pm 0.213$ & $0.19^{\mathrm{a}} \pm 0.017$ \\
\hline
\end{tabular}

${ }^{1)}$ Difference between fed group and starved group is significant at this level $(p<0.05)$. The values are means of triplicate experiments.

$\mathrm{pH}$ values and respiratory frequency (gill cover movement) between fed and starved groups. For both groups, respiratory frequency also gradually decreased until $48 \mathrm{hrs}$ and $\mathrm{pH}$ also decreased drastically until $12 \mathrm{hrs}$, and then de creased

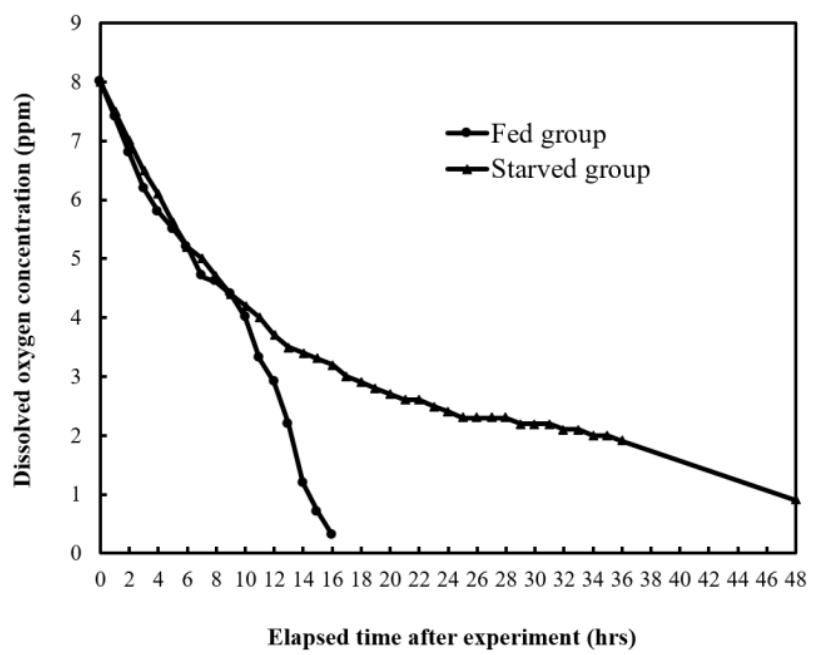

Fig. 3. Dissolved oxygen concentration between fed group and starved group on Far Eastern catfish, Silurus asotus. The values are means of triplicate experiments. gradually until $48 \mathrm{hrs}$. The respiratory frequencies of starved group were significantly higher than those of fed group, and they decreased over the elapsed time $(p<0.05)$. Therefore, it was concluded that oxygen uptake per unit of respiratory movement was lower in starved group than in fed group. The $\mathrm{CO}_{2}$ and $\mathrm{NH}_{4}{ }^{+}$concentrations increased drastically until $6 \mathrm{hrs}$, and increased gradually until $48 \mathrm{hrs}$ as shown in Table 4. The $\mathrm{CO}_{2}$ and $\mathrm{NH}_{4}{ }^{+}$of fed group were significantly higher than those of starved group, and they increased over the elapsed time $(p<0.05)$.

Dose-response mortality occurred in fish exposed to $120 \mathrm{mg} / \mathrm{L}$ of sodium nitrite at the fed group and $40 \mathrm{mg} / \mathrm{L}$ at the starved group (Fig. 4). Almost all fish survived 96 hrs of exposure to 0 and $40 \mathrm{mg} / \mathrm{L}$ of nitrite, whereas $75 \%$ and $25 \%$ of fish each survived $96 \mathrm{hrs}$ of exposure to 150 and $200 \mathrm{mg} / \mathrm{L}$ of nitrite in fed group, and 80 and $120 \mathrm{mg} / \mathrm{L}$ of nitrite in starved group respectively. The $\mathrm{LC}_{50}, 95 \%$ confidence ranges, and experimental conditions for different exposure groups are summarized in Table 5 and Fig. 5. The $\mathrm{LC}_{50}$ values for $96 \mathrm{hrs}$ were $181 \mathrm{mg} / \mathrm{L}$ at the fed group and 

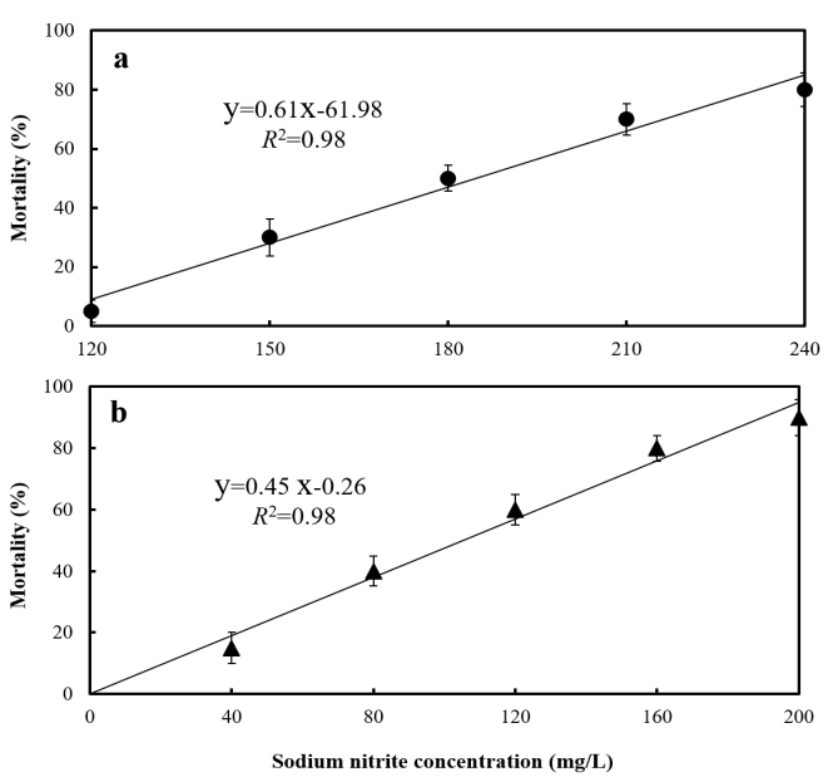

Fig. 4. Dosage-mortality response of Far Eastern catfish, Silurus asotus exposed to sodium nitrite for 96 hrs. (a): fed group $\left(\mathrm{y}=0.61 \mathrm{x}-61.98, R^{2}=0.98\right.$, where $\mathrm{y}$ is mortality and $\mathrm{x}$ is sodium nitrite concentration), and (b): starved group $(\mathrm{y}=0.45 \mathrm{x}-0.26$, $R^{2}=0.98$, where $\mathrm{y}$ is mortality and $\mathrm{x}$ is sodium nitrite concentration). Error bars represent the standard error of triplicate experiments $(p<0.05)$.

$108 \mathrm{mg} / \mathrm{L}$ at the starved group respectively.

Figs. 6, 7, and 8 are variations of hematological result for $48 \mathrm{hrs}$ of exposure to sublethal sodium nitrite. In the fed group, plasma cortisol increased significantly $(p<0.05)$ from $1.9 \pm 0.3 \mu \mathrm{g} / \mathrm{dL}$ to $30.7 \pm 2.5 \mu \mathrm{g} / \mathrm{dL}$ at $12 \mathrm{hrs}$, but $5.6 \pm 2.9 \mu \mathrm{g} / \mathrm{dL}$ at $24 \mathrm{hrs}$ and $4.8 \pm 0.7 \mu \mathrm{g} / \mathrm{dL}$ at $48 \mathrm{hrs}$ respecticely. The changes for $24 \mathrm{hrs}$ and $48 \mathrm{hrs}$ were not

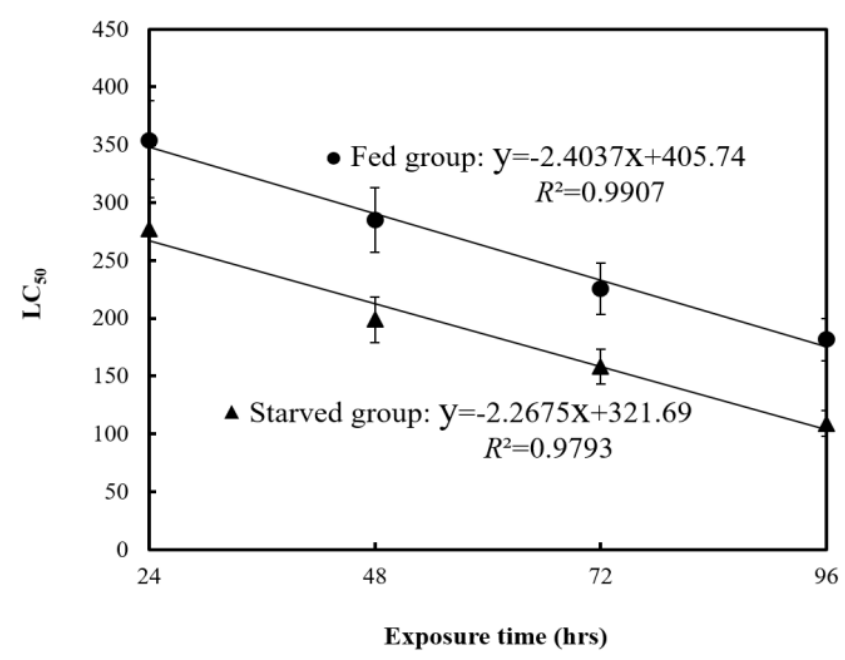

Fig. 5. Effect of starvation on $\mathrm{LC}_{50}$ changes of Far Eastern catfish, Silurus asotus exposed to sodium nitrite at each exposure time. Fed group: $y=$ $2.4037 \mathrm{x}+405.74, R^{2}=0.9907$, where $\mathrm{y}$ is $\mathrm{LC}_{50}$ and $\mathrm{x}$ is exposure time; starved group: $y=-2.2675 x+321.69$ $R^{2}=0.9793$, where $\mathrm{y}$ is $\mathrm{LC}_{50}$ and $\mathrm{x}$ is exposure time. Error bars represent the standard error of triplicate experiments $(p<0.05)$.

significant ( $p>0.05$, Fig. 6). In the starved group, plasma cortisol increased significantly $(\mathrm{p}<0.05)$ from $1.8 \pm 0.3 \mu \mathrm{g} / \mathrm{dL}$ to $16.7 \pm 2.5 \mu \mathrm{g} / \mathrm{dL}$ at $6 \mu \mathrm{hrs}$, but $5.8 \pm 2.9 \mu \mathrm{g} / \mathrm{dL}$ at 12 , $5.6 \pm 2.9 \mu \mathrm{g} / \mathrm{dL} 24 \mathrm{hrs}$, and $4.8 \pm 0.7 \mu \mathrm{g} / \mathrm{dL} 48 \mathrm{hrs}$ respectively however, the changes for 12, 24, and $48 \mathrm{hrs}$ were not significant ( $p>0.05$, Fig. 6). The glucose concentrations of the two groups increased significantly from $28.5 \pm 0.7$ $\mathrm{mg} / \mathrm{dL}$ to $242 \pm 18.4$ (fed) and $127 \pm 3.9 \mathrm{mg} / \mathrm{dL}$ (starved) at 12 hrs $(p<0.05$ for both, Fig. 7). The glucose levels of the

Table 5. The 96 hrs LC 50 values of Far Eastern catfish, Silurus asotus exposed to sodium nitrite

\begin{tabular}{cccc}
\hline \hline $\begin{array}{c}\text { Experimental } \\
\text { group }^{1)}\end{array}$ & $\begin{array}{c}96 \text { hrs LC }_{50}(\mathrm{ppm}) \\
{[95 \% \text { confidence ranges }]}\end{array}$ & \multicolumn{2}{c}{ Experimental conditions $^{2)}$} \\
\cline { 3 - 4 } Fed group & $181.53[171.30-199.86]$ & $\mathrm{pH}$ & $7.3 \pm 0.61$ \\
Starved group & $108.92[81.00-123.44]$ & $8.1 \pm 0.41$ & $7.4 \pm 0.63$ \\
\hline
\end{tabular}

\footnotetext{
${ }^{1)}$ Fed group ( $345 \pm 20.1 \mathrm{~mm}$ : mean body length $\pm \mathrm{SD} ; 562 \pm 52.8 \mathrm{~g}$ : mean body weight $\left.\pm \mathrm{SD}\right)$, starved group (243 $\pm 11.6 \mathrm{mm:}$ mean body length $\pm \mathrm{SD} ; 246 \pm 45.8 \mathrm{~g}$ mean body weight $\pm \mathrm{SD})$. The values are means of triplicate experiments.

${ }^{2)} \mathrm{DO}$, dissolved oxygen, $\mathrm{mg} / \mathrm{L}$; Saturated concentration in $26^{\circ} \mathrm{C}$.
} 


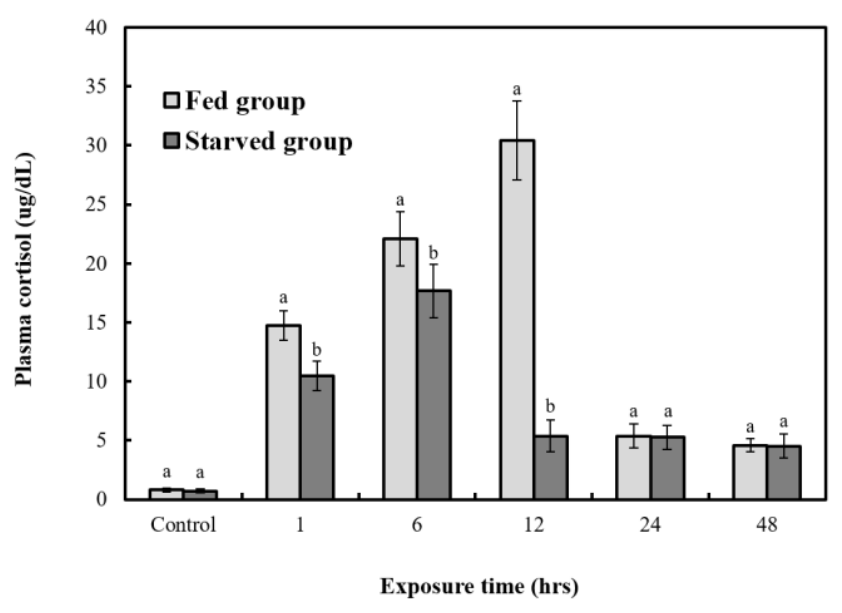

Fig. 6. Variations in the plasma cortisol concentrations in the blood plasma of the Far Eastern catfish, Silurus asotus, during 48 hrs experiment. Values are means $\pm \operatorname{SE}(n=30)$. Actually $n=5$ for each experiment because the means and SE were calculated separately for each group.

fed and starved groups differed significantly from $1 \mathrm{hr}$ to $48 \mathrm{hrs}(p<0.05)$. At $12 \mathrm{hrs}$, the cortisol and glucose levels of the fed and starved groups reached the most significant difference $(p<0.05)$. Lactic acid of fed and starved groups increased until $48 \mathrm{hrs}$, but no significant difference between fed group and starved group was found ( $p>0.05$, Fig. 8).

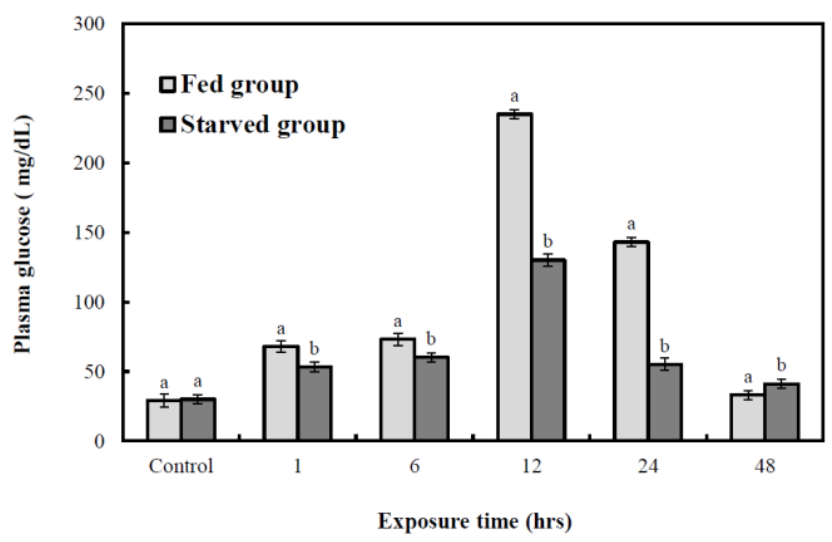

Fig. 7. Variations in the plasma glucose concentrations in the blood plasma of the Far Eastern catfish, Silurus asotus, during 48 hrs experiment. Values are means $\pm \operatorname{SE}(n=30)$. Actually $n=5$ for each experiment because the means and SE were calculated separately for each group.

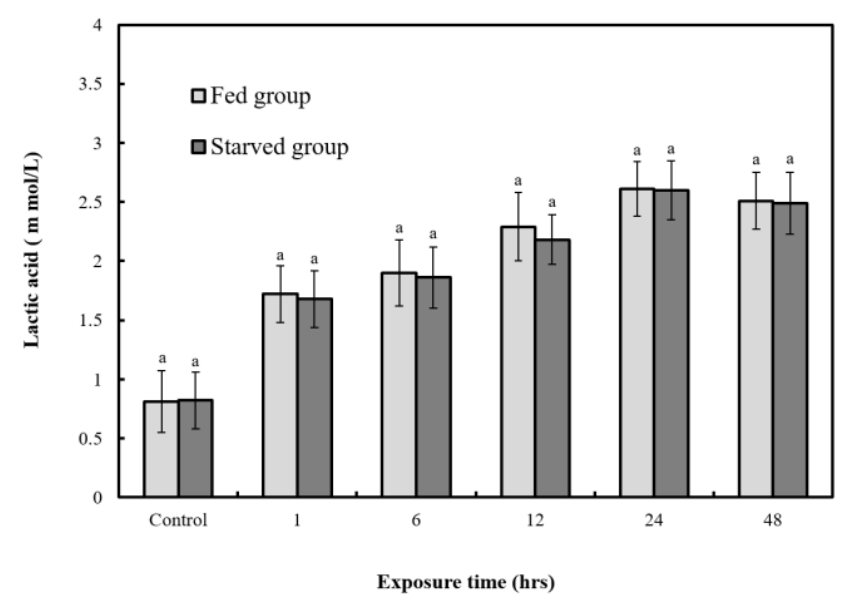

Fig. 8. Variations in the lactic acid concentrations in the blood plasma of the Far Eastern catfish, Silurus asotus, during 48 hrs experiment. Values are means \pm SE $(n=30)$. Actually $n=5$ for each experiment because the means and SE were calculated separately for each group.

\section{DISCUSSION}

Larsson and Lewander (1973) noted that many fish undergo natural periods of starvation at a particular time every year and have consequently evolved the ability to withstand the prolonged food shortages. Such periods may amount to weeks, months, or even years, and may cause extensive loss of energy stores in the body as fish consumes its own tissues to remain alive (Weatherley \& Gill, 1987; Park et al., 2015). This study shows that, Far Eastern catfish, Silurus asotus can tolerate the long term of food shortage for 210 days from the experimental proof.

When a fish is exposed to chronic stress, its metabolic reactions are altered by changes in the hypothalamicpituitary-adrenocortical axis (HPA axis), including the hypothalamic secretion of corticotropin-releasing hormone $(\mathrm{CRH})$ through the limbic system. CRH stimulates the release of adrenocorticotropic hormone (ACTH) from the pituitary gland, which then stimulates the release of cortisol from the target organ, and the interrenal gland which promots a metabolic stress reaction. Thus, cortisol is an important index of the stress reaction (Specker \& Schreck, 
1980). Severe starvation results in coma and catabolic disease of the gastrointestinal system. Basic metabolic reactions maintain energy level and body tissue (Jung et al., 2003). Guyton (1991) reported three stages of physiological change during starvation: in the first stage, the glycogen stored for urgent use is hydrolyzed, releasing glucose; in the second stage, acetyl-CoA is oversupplied, leading to acidosis; in the third stage, fish are compromised by protein exhaustion. In the process of starvation, sugar, lipid, protein, and other essential nutritional elements decrease rapidly, and finally, the whole abnormalities in immune, circulatory, and endocrine systems lead to death. In our study, dissolved oxygen concentration of starved groups decreased until $48 \mathrm{hrs,} \mathrm{and} \mathrm{fed} \mathrm{groups} \mathrm{until} 16 \mathrm{hrs}$. Respiratory frequency also gradually decreased until $48 \mathrm{hrs}$. That is, respiratory function of all experimental groups decreased during the experimental period. Comparing the dissolved oxygen, $\mathrm{pH}, \mathrm{CO}_{2}$, and $\mathrm{NH}_{4}{ }^{+}$concentrations showed different trend, but rates of $\mathrm{pH}, \mathrm{CO}_{2}$, and $\mathrm{NH}_{4}^{+}$concentrations change were similar to oxygen consumption rate. That is, the metabolic rate of all experimental groups decreased during experimental period.

The toxicity and effect of nitrite vary among fish species and depend on test conditions, such as fish size, water ion composition, and temperature (Doblander \& Lackner, 1997). Chloride and other anions in water provide protective action against nitrite in active branchial uptake (Williams \& Eddy, 1986); thus, small amounts of $\mathrm{Cl}^{-}$, for example, $1 \mathrm{mM}$, are likely to afford protection against high nitrite inputs (Eddy et al., 1983). The effect of sodium nitrite $\left(\mathrm{NaNO}_{2}\right)$ on fish is more intense in $\mathrm{Cl}^{-}$-poor freshwater. Thus, $\mathrm{NaNO}_{2}$ is more toxic in freshwater than in seawater (Grosell \& Jensen, 1999).

Plasma $\mathrm{NaNO}_{2}$ accumulation probably causes methemoglobinemia and malfunction of hemopoietic activity, which are detectable effects of $\mathrm{NaNO}_{2}$ intoxication (Costa et al., 2004). Although methemoglobinemia is not directly related to high mortality in fish exposed to $\mathrm{NaNO}_{2}$, the passing through of $\mathrm{NaNO}_{2}$ into the blood stream may cause an increase in blood cell lysis, changes in the plasma electrolyte balance, and efflux of $\mathrm{K}^{+}$from red blood cells, which is evident from the increase in the number of shrunken RBCs (Knudsen \& Jensen, 1997; Huertas et al., 2002; Martinez \& Souza, 2002; Costa et al., 2004). The dysfunctional erythrocytes may be removed from the blood circulation because of an oxygen shortage, causing reduction in the total erythrocyte counts (Park et al., 2007). For this reason, a significant difference was caused between fed and starved group in this experiment.

Plasma cortisol and plasma glucose are recognized as useful indicators of stress in fish (Park et al., 2008). Plasma cortisol and glucose levels in red drum, Sciaenops ocellatus simultaneously exposed to stressor were reported to be elevated (Massee et al., 1995). Barton and Iwama (1991) stated that "In general, the phenomenon that plasma cortisol concentration of fish rises by stress is first order reaction, and the phenomenon that plasma glucose concentration rises is the second-order reaction by hormone rise caused by stress". This finding has been reported in gray mullet, Mugil cephalus and kelp grouper, Epinephelus bruneus (Park et al., 2008). In this study, we have investigated the effect of starvation on Far Eastern catfish, exposed to the stress of $\mathrm{NaNO}_{2}$. In this study, it may safely be said that we have found out a useful index for recognizing the nutritional state of Far Eastern catfish in both fed and starved group experiencing the exposure to $\mathrm{NaNO}_{2}$.

\section{ACKNOWLEDGEMENTS}

We are grateful to anonymous reviewers for their valuable constructive comments and suggestions in improving this manuscript. We declare that all experiments in this sutdy comply with the current laws of Korea (Ordinance of Agriculture, Food and Fisheries, No. 1 and law Regarding Experimental Animals, No. 9932). 


\section{REFERENCES}

Barton BA, Iwama GK (1991) Physiological changes in fish from stress in aquaculture with emphasis on the response and effects of corticosteroids. Ann Rev Fish Dis 1:3-26.

Cech JJ (1990) Respirometry. In: Shreck CB, Moyle PB (ed), Methods for Fish Biology. American Fishery Society, Bethesda, pp 125-130.

Chavin W, Young JE (1970) Factors in the determination of normal serum glucose levels of goldfish, Carassius auratus L. Comp Biochem Physiol 33:629-653.

Costa OTF, Ferreira DJS, Mendonca FLP, Fernandes MN (2004) Susceptibility of the Amazonian fish, Colossoma macropomum (Serrasalminae), to short-term exposure to nitrite. Aquaculture 232:627-636.

Doblander C, Lackner R (1997) Oxidation of nitrite to nitrate in isolated erythrocytes: A possible mechanism for adaptation to environmental nitrite. Can J Fish Aquat Sci 54:157-161.

Duncan DB (1995) Multiple range and multiple F tests. Biometrics 11:1-42.

Eddy FB, Kunzlik PA, Bath RN (1983) Uptake and loss of nitrite from the blood of rainbow trout, Salmo gairdneri Richardson, and Atlantic salmon, Salmo salar L. in fresh water and in dilute sea water. J Fish Biol 23:105-116.

Gil HW, Lee TH, Han HJ, Park IS (2017) Comparative analysis of tissue and cell cycle on the far eastern catfish, Silurus asotus between diploid and triploid. Dev Reprod 21:193-204.

Grosell M, Jensen FB (1999) $\mathrm{NO}_{2}^{-}$uptake and $\mathrm{HCO}_{3}{ }^{-}$excretion in the intestine of the European flounder (Platichthys flesus). J Exp Biol 202:2103-2110.

Guyton AC (1991) Textbook of medical physiology. In: Wonsiewiez MJ and Hallowell R (eds), Textbook of Medical Physiology. 8th ed. WB Saunders Company, Philadelphia p 782.
Huertas M, Gisbert E, Rodriguez A, Cardona L, Williot P, Castello-Orvay F (2002) Acute exposure of Siberian sturgeon (Acipenser baeri, Brandt) yearlings to nitrite: median-lethal concentration $\left(\mathrm{LC}_{50}\right)$ determination, haematological changes and nitrite accumulation in selected tissues. Aquat Toxicol 57:257-266.

Ince BW, Thorpe A (1976) The effects of starvation and force-feeding on the metabolism of the Northern pike, Esox lucius L. J Fish Biol 8:79-88.

Jo J-Y, Kim YH (1999) Oxygen consumption of Far Eastern catfish, Silurus asotus on the different water temperatures and photoperiods. J Korean Fish Soc 32:5661.

Jung MH, Youn JM, Lee TH (2003) Effect of liriopis tuber on the change of corticosterone in mice induced by starvation stress. Korea J Herbol 18:279-287.

Kim BS, Park I-S, KIM HS (2012) Effect of starvation on growth and hepatocyte nuclear size of larval haddock, Melanogrammus aeglefinus. Dev Reprod 16:107-112.

Kim DS, Cho HJ, Park IS, Choi GC, Nam YK (2001) Cytogenetic traits and gonad development of induced triploidy in far eastern catfish (Silurus asotus). Korean J Genet 23:55-62.

Knudsen PK, Jensen FB (1997) Recovery from nitriteinduced methaemoglobinaemia and potassium balance disturbances in carp. Fish Physiol Biochem 16:1-10.

Larsson A, Lewander K (1973) Metabolic effects of starvation in the eel, Anguilla anguilla L. Comp Biochem Physiol A 44:367-374.

Martinez CBR, Souza MM (2002) Acute effects of nitrite on ion regulation in two neotropical fish species. Comp Biochem Physiol 133A:151-160.

Massee KC, Rust MB, Hardy RW, Stickney RR (1995) The effectiveness of tricaine, quinaldine sulfate and metomidate as anesthetics for larval fish. Aquaculture 134:351-359.

Mehner T, Wieser W (1994) Energetics and metabolic correlates of starvation in juvenile perch, Perca fluviatilis. 
J Fish Biol 45:325-333.

Moon TW. (1983) Metabolic reserves and enzyme activities with food deprivation in immature American eels, Anguilla rostrata (Lesueur). Can J Zool 61:802-811.

Mustafa S, Mittal A (1982) Protein, RNA and DNA levels in liver and brain of starved catfish, Clarias batrachus. Jpn J Ichthyol 28:396-400.

Park IS, Choi HJ, Noh CH, Myoung JG, Park HJ, Goo IB (2013) Induced morphological changes in larval rock bream, Oplegnathus fasciatus, under starvation. Dev Reprod 17:399-407.

Park IS, Gil HW, Yoo GY, Oh JS (2015) Effects of starvation in rock bream, Oplegnathus fasciatus and olive flounder, Paralichthys olivaceus. Dev Reprod 19:97109.

Park IS, Im JH, Ryu DK, Nam YK, Kim DS (2001) Effect of starvation on morphometric changes in Rhynchocypris oxycephalus (Sauvage and Dabry). J Appl Ichthyol 17:277-281.

Park IS, Lee JH, Hur JW, Song YC, Na HC, Noh CH (2007) Acute toxicity and sublethal effects of nitrite on selected hematological parameters and tissues in darkbanded rockfish, Sebastes inermis. J World Aquac Soc 38:188-199.

Park MO, Hur WJ, Im SY, Seol DW, Lee JH, Park IS (2008) Anaesthetic efficacy and physiological responses to clove oil-anaesthetized kelp grouper Epinephelus bruneus. Aquac Res 39: 877-884.

Peltier W (1978) Methods for measuring the acute toxicity for effluents to aquatic organisms. Environmental Protection Agency, Office of Research and Development, National Technical Information Service, Springfield, Virginia, USA.

Rios FS, Kalinin AL, Rantin FT (2002) The effects of long-term food deprivation on respiration and haematology of the neotropical fish Hoplias malabaricus. J Fish Biol 61:85-95.

Specker JL, Schreck CB (1980) Stress responses to transportation and fitness for marine survival in coho salmon, Oncorhynchus kisutch smolts. Can J Fish Aquat Sci 37:765-769.

Sumpter JP, Le Bail PY, Pickering AD, Pottinger TG, Carragher JF (1991) The effect of starvation on growth and plasma growth hormone concentrations of rainbow trout, Oncorhynchus mykiss. Gen Comp Endocrinol 83: 94-102.

Tashima L, Cahill GF (1968) Effects of insulin in the toadfish, Opsanus tau. Gen Comp Endocrinol 11:262-271.

Weatherley AH, Gill HS (1987) The Biology of Fish Growth. 4. Protein, Lipid and Caloric Contents. London, Academic Press. pp 139-146.

Williams EM, Eddy FB (1986) Chloride uptake in freshwater teleosts and its relationship to nitrite uptake and toxicity. J Comp Physiol B 156:867-872. 